\title{
パーフルオロアルカノイルパーオキサイドによる 絹の表面改質
}

$\begin{array}{llr}\text { 大阪市立大学生活科学部 } 川 \text { 瀬 徳三・花田 } & \text { 幸子 } \\ & \text { 藤井富美子. 皆川 } & \text { 基 } \\ \text { 奈良工業高等専門学校 } & \text { 沢田 英夫 } & \\ \text { 日本油脂株式会社 } & \text { 松本 竹男. 森屋 } & \text { 泰夫 }\end{array}$

\section{Surface Modification of Silk Fabric with Perfluoroalkanoyl Peroxide}

\author{
Tokuzo Kawase ${ }^{* 1}$, Sachiko Hanada ${ }^{* 1}$, Tomiko Fujii ${ }^{* 1}$, Motoi Minagawa ${ }^{* 1}$, Hideo Sawada ${ }^{*}$, \\ Takeo Matsumoto ${ }^{* 3}$, and Yasuo Moriya ${ }^{* 4}$ \\ ${ }^{*}$ Faculty of Life Science, Osaka City University, 3-3-138 Sugimoto, Sumiyoshi-ku, Osaka, 558 Japan \\ * 2Department of Chemistry, Nara National College of Technology, 22 Yata, Yamatokouriyama, Nara, 639-11 \\ Japan \\ ${ }^{*}$ Tsukuba Research Lab., NOF Corporation, Tsukuba, 300-26 Japan \\ ${ }^{*}$ Chemical Division, NOF Corporation, 1-10-1 Yurakucho, Chiyoda-ku, Tokyo, 100 Japan
}

\begin{abstract}
Perfluoroalkanoyl peroxides (PFPO) were applyed to the surface modification of silk fabrics. The modification with PFPO proceeded under quite moderate conditions. PFPO reacted specifically with tyrosine residues of silk on the surface, and hydrophobic perfluoroalkyl groups were introduced to the surface effectively. The modification with PFPO influenced the wettability and electrostatic property of silk fabric. Based on the results of ESCA analysis, the amounts of fluorine atoms on the surface were less than those by the $\mathrm{CF}_{4}$ plasma modification. Moreover, the PFPO modification did not influence significantly the bulk properties, such as tensile stress and fabric hand. On the other hand, the PFPO modification lowered the light-resistance of silk. A possible reason was proposed based on a molecular orbital calculation for perfluoroalkyl-substituted tyrosine
\end{abstract}

(Received June 6, 1994).

\section{1. 粕言}

フッ素化合物は一般に低表面エネルギーを有する事か ら，撥水・撥油を目的とした各種工業製品の界面制御人 の応用が検討されている。栈維の分野でも，撥水・撥油 性の付与を目的として，含フルオロアルキルポリマーに よる樹脂加工 [1，2]，フッ素ガスによる直接フッ素化 [3] や $\mathrm{CF}_{4}$ などのフッ化炭素モノマーを用いたブラズマ好理 [4,5]などの表面フッ素化が研究されてきた。

しかし，樹脂加工では風合いの変化や洗浄などによる 加工剂の脱落，直接フッ素化では排ガス処理，またブラ ズマ処理ではプラズマの表面エッチングによる外観の变 化や強度の低下なと〔4]が問題として残されており，新
たな表面フッ素化の開発が望まれている。 本研究で用いるパーフルオロアルカノイルパーオキサ イド（PFPO）[6]は，一般のアルカノイルパーオキサ1 ドと異なり，電子吸引性の高いフッ素原子の導入により 中央部の $\mathrm{O}-\mathrm{O}$ 結合の反結合性 $2 \mathrm{p} \sigma *$ *軌道（最低空軌 道，LUMO）のエネルギー集位が著しく低下しているた めに特異な反応性を有している。例之ば，通常，アルカ ノイルパーオキサイドの单独分解では脱炭酸を伴わない アシロキシル基（RCOOー）の関与した生成物が得られ るのに対し(7)，PFPOのフロン中での単独分解ではカッ プリング生成物のみが得られる[6]。

一方, Yoshida ら [8] は PFPO とベンゼン類との反応 で，パーフルオロアルキル基が置換した生成物が收率良 
く得られると同時に等モルのパーフルオロカルボン酸が 副生する事から，図1に示すベンビン類の HOMO と PFPOの LUMO との相互作用による電子移動により反 応が進行する事を明らかにしている。

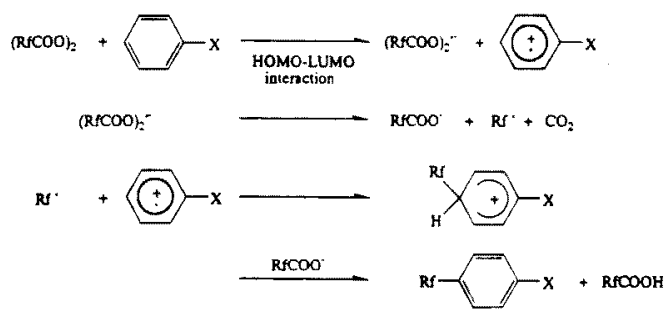

Fig. 1 Mechanism of perfluoroalkylation of substituted benzene derivatives with perfluoroalkanoyl peroxide.

この芳香族化合物との選択的な反応性に注目して，ポ リスチレン [9]やポリエステル (10)などの芳香環を有す る高分子材料の表面改質郕としての応用について検討し， PFPO は非常に温和な条件で反応し，優れた表面改質効 果を与える事を報告してきた。

高級峨維の代名詞とされる絹は，蛋の品種や飼育条件 により差翼はあるが，化学組成的にはグリシン，アラニ ン，セリン，チロシンの 4 種のアミノ酸が全体の $90 \%$ 以 上を占めており，この中で芳香環をもつチロシンは含有 率10\%とかなりの部分を占めている $[11\} 。$ 従って, PFPOを組に応用寸れば，PFPOはチロシンの芳香環と 選択的に反応し，フルォロアルキル基を絹表面に導入で きることが期待される。本研究では，PFPOの絹の表面 改質郕としての可能性を娭討する目的で，各種 PFPOを 用いて絹峨維の表面フルオロアルキル化を行い，表面特 性を中心として改質にともなう各種傤維性能の変化につ いて調べた。

\section{2. 実 食}

\section{1 試料}

綃桟維試料は，絹12多付羽二重（福井産・平織）で, 織密度は経 58 本 $/ \mathrm{cm}$ ，䋨 36 本 $/ \mathrm{cm}$ で，系は経 2 本撚， 緯 3 本撚である。試料は炭酸ナトリウム $0.1 \%$ owf（浴 比 1：30,50 ${ }^{\circ}$ ）で 2 回洗净し, 温湯で充分洗浄後,
さらにエタノールで精製し風乾させた。

表面改質戍としては，表 1 に示すフルオロアルキル基 (Rf）の異なる 3 畽のパーフルオロアルカノイルパー才 キサイド（PFPO）を常法[6]に従い合成し，単踓するこ となくフレオン113溶液のまま用いた。

\subsection{PFPOによるフルオロアルキル化}

$20 \times 20 \mathrm{~cm}^{2}$ と $10 \times 10 \mathrm{~cm}^{2}$ に切断した絹布各 1 枚を PFPO 湿度 5-6\%のフレオン 113 溶液 $200 \mathrm{~cm}^{3}$ 中に浸漬し， 35 Cの温度条件のもとで反応時間を10分，30分，60分の 3 段階に変化させて改質を行った。反応終了後，絹布を引 き上げフレオン113で洗浄し，風乾した。

\section{3 测 定}

\subsubsection{ESCA 分析}

フルオロアルキル化した綟布を島津 X 線光電子分析装 置 ESCA 750 (X 線源, MgK $\alpha$ ) を用い， $\mathrm{C}_{\mathrm{ls}}, \mathrm{N}_{\mathrm{ls}}, \mathrm{O}_{\mathrm{ls}}$,

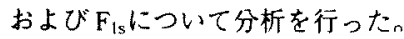

\subsection{2 引張り強度}

引張り強度は。オリエントINTESCO Model 2050によ

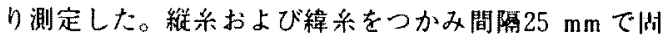
定し，速度毎分 $30 \mathrm{~mm}$ で試料を引張り，切断強度（g）を 求めた。

\subsection{3 広角 $X$ 線回析}

理学電機製 $\mathrm{X}$ 線回折装置を使用 $L, \mathrm{Cu}-\mathrm{K} \boldsymbol{\alpha}$ 線を光 源として, 一定長 $(2 \mathrm{~cm})$ の絸系120本について広角 X線写真を撮影した。測定に当たっては，X線入射部分 の試料条件が出来る限り同じとなるように，長さ，本数 などをそろえて行った。

\subsection{4 性}

ぬれ性の評価は，試料布中への水の毛管上昇時におけ る wetting force $\left(\mathrm{F}_{\mathrm{W}}\right)$ 測定加求まる見かけ㢺触角 を用いて行った。以下にその原理を示す。

固体が液体に接触したとき，液体は固体の壁面をつた わって上年もしくは下降する。このとき垂直方向に働く 引力 $\mathrm{F}_{\mathrm{W}}$ は次式で表わされる(12)。

$\mathrm{F}_{\mathrm{W}}=\gamma_{\mathrm{LV}} \mathrm{P} \cos \theta$

ここで， $\gamma_{\mathrm{LV}}$ は液体の表面張力，P は固液界面の凬用 長である。

Table 1 List of Perfluoroalkanoyl Peroxides (PFPO)

\begin{tabular}{|c|c|c|c|}
\hline Formula & $\mathrm{Rf}$ & & Abbreviation \\
\hline \multirow{3}{*}{$\begin{array}{cc}\mathrm{Rf}-\mathrm{CO}-\mathrm{OC}-\mathrm{Rf} \\
\| & \| \\
0 & 0\end{array}$} & $\mathrm{C}_{3} \mathrm{~F}_{7}$ & Bis (heptafluorobutanoyl) peroxide & $\mathrm{C} 3 \mathrm{~F} 7$ \\
\hline & $\mathrm{C}_{6} \mathrm{~F}_{13}$ & Bis (tridecafluoroheptanoyl) peroxide & $\mathrm{C} 6 \mathrm{~F} 13$ \\
\hline & $\underset{\mid}{\mathrm{CF}_{3} \mathrm{~F}_{7}}-\mathrm{O}-\mathrm{CF}-$ & $\begin{array}{l}\text { Bis (undecafluoro } 2 \text {-methyl }-3 \text {-oxa hexanoyl) } \\
\text { peroxide }\end{array}$ & $\mathrm{CFO}$ \\
\hline
\end{tabular}




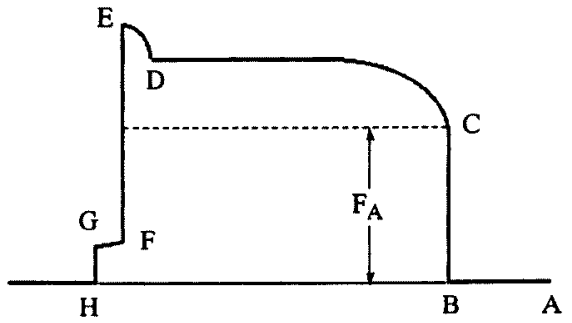

Fig. 2 Typical diagram of wetting and transport of water by silk fabric.

完全に固体表面を如す液体では接触角 $\theta=0$ ( $\cos$ $\theta=1)$ となる。このときの wetting force を $\mathrm{F}_{0}$ とする と周囲長 P は

$$
\mathrm{P}=\mathrm{F}_{0} / \gamma_{\mathrm{LV}}
$$

で求まる。

この周用長 P と表面張力の分かっている液体を用いた ときの $\mathrm{F}_{\mathrm{W}}$ を測定すれば，その液体と固体との接触角 $\theta$ は次式から求まる。

$$
\cos \theta=\mathrm{F}_{\mathrm{W}} / \mathrm{P} \gamma_{\mathrm{LV}}
$$

wetting force $\left(\mathrm{F}_{\mathrm{W}}\right)$ の測定は, 微小電子天科 $\mathrm{CAHN}$ -2000 (CAHN 社) を使用した。 $50.0 \times 5.0 \mathrm{~mm}^{2} に$ に切断 した絹布（周囲長 $\mathrm{P}=1.00 \mathrm{~cm}$ ）の上端にフック状にし た白金線を通し張力測定装置に垂直に吊り下げる。

Inchworm (Berleigh 社)により $25^{\circ} \mathrm{C}$ 恒温に保った水 槽をゆっくりと上昇させ、試料の下端が水面に接触した 瞬間に停止させる。吸水が飽和に達した後，水槽を一定 速度で降下させ液面から布の下端が完全に離れるまで測 定を続けた。

得られた典型的な吸水曲線を图 2 に示す。A-B間は 布が液体に接する前の張力ゼロを表す。B-D間は，布 が液体に接してから毛管上昇により吸水されていく過程 を表す。Bで下端が水面と接し、瞬時にCに到る。この ときのB-Cの力は，固体が液体に接したときにかかる 前進の wetting force $\left(\mathrm{F}_{\mathrm{A}}\right)$ である。C-Dの緩やかな增 加曲線は、飽和状態に到るまでの毛管上昇による吸水過 程である。一方，D－Eは液体から布を引き離す過程で ある。

本研究では，䄉維集合体である布を㨁接用いているた め周用長 Pはみかけの周囲長であり，式 3 から求まる接 触角は見加けの前進接触角 $\phi_{\mathrm{A}}$ である。

\subsection{5 带電性}

带電性は，JIS L1094-1988に染扰してA 法の半隇期測 定法およびB法の摩擦帯電圧湘定法により行った。A 法
の試験片の大きさは $45 \times 45 \mathrm{~mm}^{2}$ とし，B法の試験片は $50 \times 80 \mathrm{~mm}^{2}$ とした。原則として70で1時間予備乾燥 した後，温度 $20 \pm 2{ }^{\circ} \mathrm{C}$, 相対湿度 $20 \pm 2 \% に$ 保たれた 恒温恒湿空に24時間以上放置し平衡状態とした。

A 法はオネストメーター（日本スタティック甡Type S-4104）を使用し，印加電圧＋10 kVで行った。本研 究では，3 分後の带電压を読みとり初期带電压に対する 残存率の值で評価した。

B 法はロータリ一型摩擦带電圧測定機（浅野機械製作 (侏)をを使用し，摩擦布にはJIS L0803に規定された䄸添 白布を使用して摩擦開始から60秒後の帯電压（V）を測 定した。

\subsection{6 風合い}

改質に伴う布の風合いの変化は，KESーF システムを 用いて布の基本力学特性值を計測し，婦人外衣用薄地に ついての $\mathrm{X}_{\mathrm{i}}, \sigma, \mathrm{Ci}[13] \sigma$ 值を用いて風合い変換式 から KOSHI, HARI, SHARI, FUKURAMI, KISHIMI $の$ 風 合い值（HV）を算出した。

\subsection{7 面光性}

スガ紫外線ロングライフメーター（F A - 5 型）を用 い50×50 $\mathrm{mm}^{2}$ に切断した試験布を原布と一緒にカーボ ンアーク灯により照射時間 $0.5 ， 1 ， 2 ， 5 ， 10 ， 20 ， 40$ 時 間の7段階に分けて紫外線を照射し，黄変を評価した。 紫外楾照射後の試験布の黄変度は，色差計 $\Sigma 80$ (日本電 色）により $\mathrm{L}_{\mathrm{ab}}$ 測色系のb 值を求め，末照射原布のb。 値と比較することにより評価した。

\section{4 分子軌道法計篎}

改質に伴う耐光性の変化を分子レベルで検討するため に，モデル化合物にチロシンおよびトリフルオロメチル チロシンを選び、MM 2 法[14]により分子軌道䚵算を行 った。

\section{3. 結果および考察}

\subsection{PFPOによる改虿}

楮言でも述べたように，PFPOは芳香族化合物と選択 的に反応するという特異なパーオキサイドである。絠を 構成するアミノ酸の約10\%を占めるチロシンは，フェノ

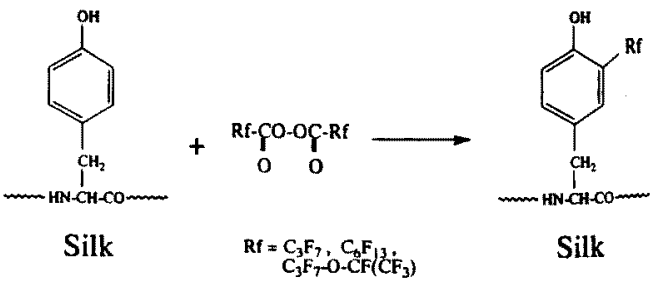

Fig. 3 Scheme of modification of tyrosine residues in silk with PFPO. 
ール基を持つことから，PFPOは図 3 のスキームでチロ シンの芳香環と選択的に反応し，フルオロアルキル基が 遒入されることが期待される。

PFPOによる改質は, 使用したPFPOの分解温度 (Rf により異なるが大体 $35{ }^{\circ} \mathrm{C}$ 付近）のフロン溶液に一定時

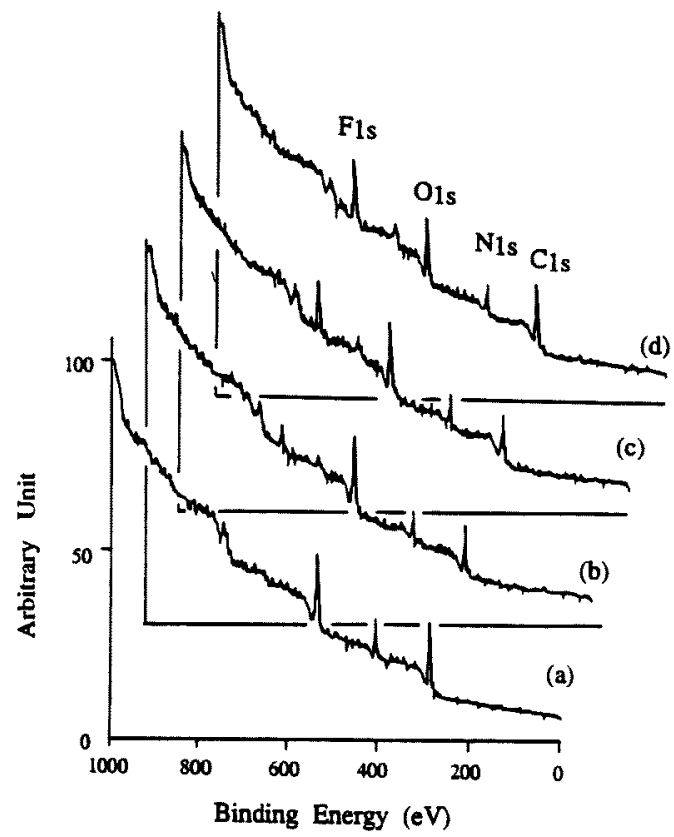

Fig. 4 ESCA survey spectra of silk fabrics modified with C6F13: (a) Original; (b) C6F 13 for $10 \mathrm{~min}$; (c) 30 $\min$; (d) $60 \mathrm{~min}$.

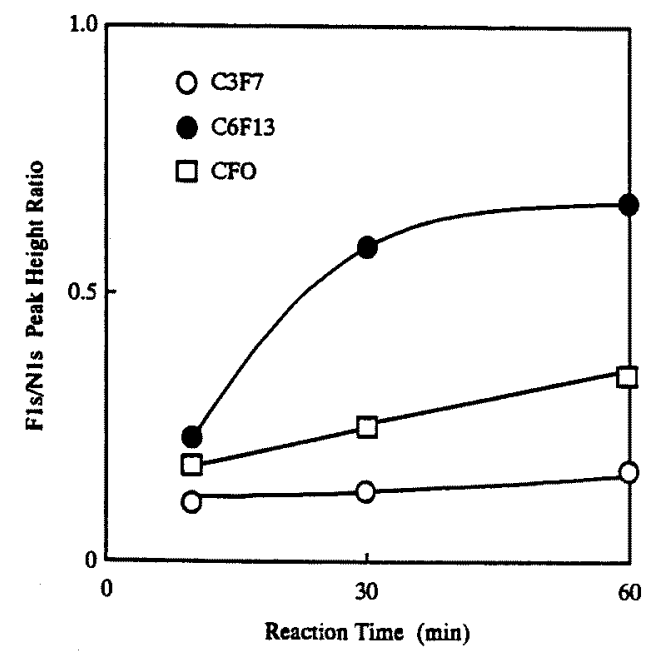

Fig. 5 Relation between ratio of $F_{1 s} / N_{1 s}$ peak height in ESCA spectra of modified silk fabrics and time of treat. ment with PFPO.
間浸漬するだけで進行する[9,10]。これは，非常に穏和 な条件であり，フロン自体はドライクリーニング溶剤と して用いられるように絹縺維の変性を起こしにくいと考 えられることから，PFPOによる改質は同じラジカル反 応であるプラズマ法と比較すると表面形態の変化〔4]な どの問題は避けられると期待される。また、絹の改質加 工では一般に重量変化が重要視されるが，本改質では変 化は全く認められなかった。

まず，綟布にフルオロアルキル基が導入されているこ とを確認するために，ESCA 表面分析を行った。 Rf= $\mathrm{C}_{6} \mathrm{~F}_{13}$ の PFPO での ESCAスペクトルを図 4 に示す。改 質絹布では $\mathrm{F}_{1 \mathrm{~s}}$ のピークが $690 \mathrm{eV}$ 付近に明瞭に現れてい ることから，表面がフルオロアルキル化されている事は 明らかである。

ESCA 分析に定量性を持たせるには，一定の基準ビー クに対するピーク強度比の值を用いる必要がある。本研 究では，改質郕PFPOには含まれず組基質にのみ含まれ る窒素原子を基準に選び，400 eV付近の $\mathrm{N}_{1 \mathrm{~s}}$ ピークの高 さを 1 として $\mathrm{F}_{\mathrm{ls}}$ のピーク強度比（高さ比）求め, PFPO 改質により表面に導入されたフッ素量を表す尺度 として採用した。

$\mathrm{F}_{\mathrm{is}} / \mathrm{N}_{\mathrm{is}}$ ピーク強度比を反応時間に対して調べた結 果を図 5 に示す。PFPOの種類に関係なく，処理時間と ともに表面フルオロアルキル化が進行し，表面フッ素量 が增大していることが定量的に示される。 $\mathrm{R}$ fによって ラジカルの反応性に差はないと思われることから，同一 時間であれば C 3 E $7<C F O （ F$ 数=11）<C 6 F13の順 にRfのフッ素数が多いはど表面フッ素量は增大してい る。特に C 6 F13は短時間で增加量が大きく，表面フッ 素量加高い。

しかし， $\mathrm{CF}_{4}$ プラズマ処理による䅌の加工[4.5]では, ESCA スペクトルにおける $C_{\mathrm{Is}}$ ピークの形状からみると もっと多くのフッ素量が導入されている。これは，反応 種が同じラジカル種であるとしても，PFPOは選択的に チロシンのみと反応するのに対し、 $\mathrm{CF}_{4}$ プラズマは主鎖 を中心としてランダムに反応するためと考えられる。

\section{2 バルク檄造变化}

PFPOによるポリエステルの改質では表面のみが有効 にフルオロアルキル化された[10]が，本研究の絹の場合 には，加工剂溶液が内部にまで浸透し内部のチロシンと も反応してバルク構造の変化を起こしている可能性もあ る。ESCA 分析では， 5-50 A のごく表面の分析は行え るものの，内部のバルク情報については知ることが難し い。この点をX線回折像を観測して検討した。

表面フッ素量の多いC6 F13による30分処理布とオリ

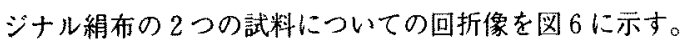


(a)

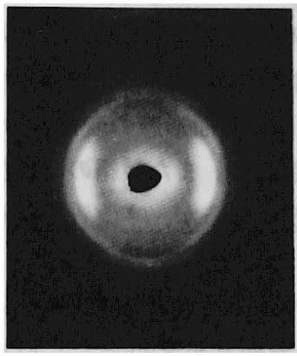

(b)

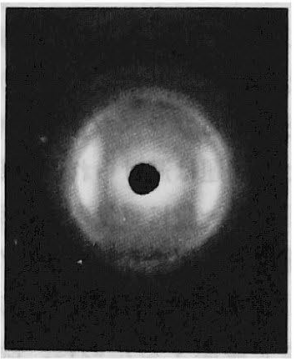

Fig. 6 Wide-angle X-ray diffraction patterns of silk fibers: (a) original silk; (b) modified silk (C6F13, 30 min).

Table 2 Effect of PFPO Modification on Tensile Stress of Silk Fabric

\begin{tabular}{ccc}
\hline $\begin{array}{c}\text { Modification } \\
\text { with PFPO }\end{array}$ & \multicolumn{2}{c}{ Tensile stress $(\mathrm{g})^{\mathrm{a})}$} \\
\cline { 2 - 3 } Original & 163.2 & Weft \\
\hline C3F7 & & 295.2 \\
$10 \mathrm{~min}$ & 157.3 & 294.2 \\
$30 \mathrm{~min}$ & 158.8 & 303.2 \\
$60 \mathrm{~min}$ & 163.2 & 298.6 \\
C6F13 & & \\
$10 \mathrm{~min}$ & 162.8 & 299.4 \\
$30 \mathrm{~min}$ & 164.7 & 296.8 \\
$60 \mathrm{~min}$ & 165.2 & 304.6 \\
CFO & & \\
$10 \mathrm{~min}$ & 135.0 & 242.7 \\
$30 \mathrm{~min}$ & 138.2 & 272.6 \\
$60 \mathrm{~min}$ & $(159.3)^{\mathrm{b})}$ & $(301.9)^{\mathrm{b})}$ \\
\end{tabular}

a) All values are the average of 5 measurements.

b) Measured after washing with water.

この像は, 試料絹系の解撚をしないで測定した結果であ り, 䋞維の微細構造の細かな変化まで議論は出来ないが, 両者の間にはほとんど変化は認められなかった。

次に, 引張り強度の変化を調べ, バルク構造の変化に ついて検討した。表 2 に示すように，CFO 改質試料の 結果を除いては改質の前後で強度には大きな変化がみら れない。これらのことから, PFPOの改質反応は表面の みで進行し, バルク構造の変化は無視できると考えられ る。

なお, CFO 改質試料では強度変化の著しいものも認
Table 3 Apparent Contact Angles for Water on Silk Fabrics Modified with PFPO at $25{ }^{\circ} \mathrm{C}$

\begin{tabular}{cc}
\hline $\begin{array}{c}\text { Modification } \\
\text { with PFPO }\end{array}$ & $\begin{array}{c}\text { Apparent } \\
\text { advancing contact } \\
\text { angle (deg) }\end{array}$ \\
\hline Original & 46.8 \\
C3F7 & \\
$10 \mathrm{~min}$ & 56.5 \\
$30 \mathrm{~min}$ & 61.3 \\
$60 \mathrm{~min}$ & 61.5 \\
C6F13 & 59.7 \\
$10 \mathrm{~min}$ & 67.8 \\
$30 \mathrm{~min}$ & 65.5 \\
$60 \mathrm{~min}$ & \\
CFO & 52.9 \\
$10 \mathrm{~min}$ & 58.5 \\
$30 \mathrm{~min}$ & 62.8 \\
$60 \mathrm{~min}$ & \\
\hline
\end{tabular}

められたが,これは改質反応後のフロン洗浄処理が不十 分で, PFPO と芳香環との反応で副生する強酸のパーフ ルオロカルボン酸が微量残留していたために強度が低下 したものと考えられた。そこで，フロン洗浄の後，さら に水洗を行った CFO 改質試料について強度を調べたと ころ，期待通り強度低下はほとんどなかった。

\section{3 れ性の変化}

PFPO は表面のみをフルオロアルキル基により疎水化 改質することから，表面が関与する諸特性のうち，特に 水の関与した性質としてぬれ性に及ほす影響について調 べた。なお，吸湿性や透湿性については，いずれの PFPO も改質の前後でほとんど变化は認められなかった。 布の織構造・密度, 系密度, 表面粗さなどが同じであ れば, 真の接触角 $\theta$ とは異なるが, 見かけの接触角を用 いて表面のぬれ性の比較が可能であると考え，本研究で は水の試料布中への毛管上昇時における見かけの接触角 $\phi_{\mathrm{A}}$ を求め検討した。

各改質綃布の見かけの前進接触角 $\phi_{\mathrm{A}}$ の值を表 3 にま とめた。 $\mathrm{R}$ f の種類に関係なく改質により $\phi_{\mathrm{A}}$ が増大 している。そこで, ESCAによる各試料布の表面フッ素 濃度 $\left(\mathrm{F}_{\mathrm{Is}} / \mathrm{N}_{\mathrm{ls}}\right)$ に対して $\phi_{\mathrm{A}}$ を図 7 にプロットした。 明らかに表面フッ素量の増大とともに，見かけの接触角 も増大している。布構造の変化は無視出来るので, この $\phi_{\mathrm{A}}$ の変化は絹表面の自由エネルギーの変化,つまりフ ルオロアルキル基の導入による表面疎水化を示している。

測定法が異なるため単純には比較出来ないが，奥野と 


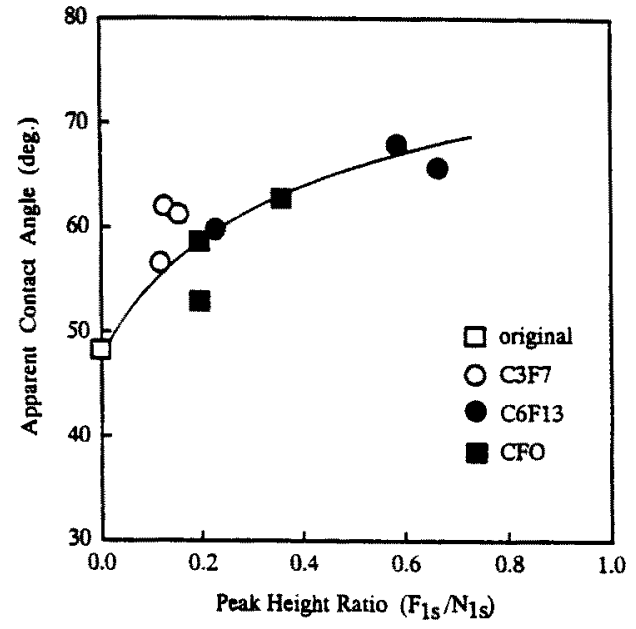

Fig. 7 Relation between apparent contact angles for water on PFPO-modified silk fabrics and their $F_{\mathrm{ls}} / N_{\mathrm{ls}}$ peak height ratios in ESCA spectra.

Table 4 Effect of PFPO Modification on Electrostatic Decay Property of Silk Fabric

\begin{tabular}{cc}
\hline $\begin{array}{c}\text { Modification } \\
\text { with PFPO }\end{array}$ & $\begin{array}{c}\text { Degree of electrostatic decay } \\
\text { after } 3 \mathrm{~min}\end{array}$ \\
\hline Original & 0.884 \\
C3F7 & \\
$10 \mathrm{~min}$ & 0.954 \\
$30 \mathrm{~min}$ & 0.963 \\
$60 \mathrm{~min}$ & 0.979 \\
C6F 13 & \\
$10 \mathrm{~min}$ & 0.957 \\
$30 \mathrm{~min}$ & 0.981 \\
$60 \mathrm{~min}$ & 0.946 \\
CFO & \\
$10 \mathrm{~min}$ & 0.954 \\
$30 \mathrm{~min}$ & 0.923 \\
$60 \mathrm{~min}$ & 0.929 \\
\hline
\end{tabular}

澤[5]のプラズマ処理された絹布では水に対するみかけ の接触角は $100^{\circ}-130^{\circ}$ の值を示し撥水性になると報告さ れている。ESCA 分析でも述べた様に，PFPO 処理では チロシンのみがフルオロアルキル化されるのに对し，プ ラズマ処理では高分子全体がフッ素化され，表面フッ素

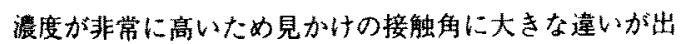
たのであろう。この点はPFPOのRfを変えることによ り解消出来ると考えている。

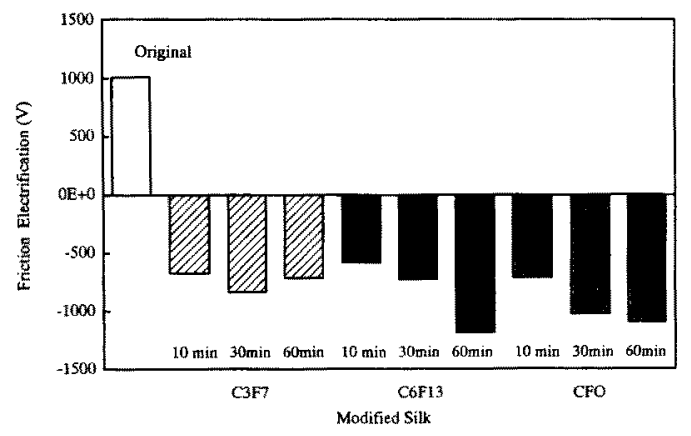

Fig. 8 Effect of modification with PFPO on friction electrification of silk fabric against cotton.

\section{4 带䉓性}

表面を踈水化した場合，带電に関係した性質にも影響 することが予想される。そこで，摩擦帯電も含め带電性 の変化を測定した。なお，JIS法では20 ゚，40\%での測 定を規定しているが，影翼を大きく反映させるために本 研究では20 $\mathrm{C}$ ，20\%の条件下で測定した。

半隇期法による测定では，末加工の絹布でも規定の測 定時間範用内で注 $50 \%$ の低下(半堿期)を示さなかった ので, 測定開始俊 3 分における初期带電值に対する带電 残存率の值で評価した。結果を表 4 に示すが，表面フル オロアルキル化により，Rfの種類に関係なく明らかに 制電性が低下している。

一方、綿を摩擦布とした摩擦带電圧法による測定結果 を图 8 に示す。未加工蝞布の場合には，䄪+1000Vの

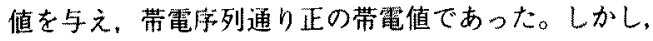
非常に奇妙なことに，表面がフルオロアルキル化される と $-500 \mathrm{~V}-1200 \mathrm{~V}$ 带電序列加らの予想に反して 鱼の带電圧㨁を与えた。

制電性の低下は㻋水化で説明できるが，この摩擦带電 压の符号の逆転現象はうまく説明できない。フルオロア ルキル化による表面近傍の誘電率の変化が原因の1つと 思われるが、さらに検計が必要である。

\section{5 凰合い}

絹には独特の風合いがある。そこで，本研究の改質が

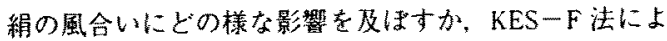
り布の基本力学特性および表面特性を测定し，婦人外衣 用薄地として風合い値（HV）を算出して検討した。

基本力学特性および表面特性值について，改㑭で変化 が認められる項目とほとんど変化がない項目との2つに 分けると，曲げヒステリシス $(2 \mathrm{HB} / \mathrm{B})$ ，世人断剛性

(G)，せん断とステリシス $(2 \mathrm{HG} / \mathrm{G})$ ，引張レジリ エンス（RT)，摩擦係数（MIU）については改貿により

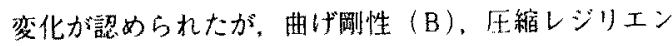


Table 5 Effect of PFPO Modification on Hand Value of Silk Fabric

\begin{tabular}{ccccccc}
\hline \multirow{2}{*}{$\begin{array}{c}\text { Modification } \\
\text { with PFPO }\end{array}$} & Koshi & Hari & Shari & Fukurami & Shinayakasa & Kishimi \\
\hline & 7.60 & 8.39 & 10.20 & 8.14 & 4.12 & 4.32 \\
Original & & & & & \\
C3F7 & & & & & \\
$10 \mathrm{~min}$ & 8.09 & 9.00 & 9.92 & 6.00 & 3.72 & 4.14 \\
$30 \mathrm{~min}$ & 8.47 & 8.79 & 9.14 & 7.20 & 4.06 & 2.45 \\
$60 \mathrm{~min}$ & 8.44 & 8.60 & 9.63 & 8.17 & 4.27 & 2.36 \\
C6F13 & & & & & \\
$10 \mathrm{~min}$ & 7.46 & 8.90 & 10.03 & 6.43 & 4.07 & 3.16 \\
$30 \mathrm{~min}$ & 8.18 & 8.90 & 10.32 & 7.28 & 3.70 & 3.44 \\
$60 \mathrm{~min}$ & 7.62 & 8.71 & 9.81 & 8.05 & 4.01 & 4.20 \\
CFO & & & & & 3.86 \\
$10 \mathrm{~min}$ & 8.26 & 8.65 & 9.76 & 6.36 & 3.88 & 3.99 \\
$30 \mathrm{~min}$ & 7.94 & 8.82 & 9.38 & 6.60 & 5.22 & 3.95 \\
$60 \mathrm{~min}$ & 7.93 & 8.41 & 9.80 & 5.76
\end{tabular}

又 $(\mathrm{RC})$ ，圧縮仕事量（WC／T），表面凹凸変動 (SMD), 厚さ (T) 㧍よび重量 (W)にはほとんど変 化はなかっった。

これらの值から算出した風合い俌を表 5 に示す。項目 別にみると, KOSHI, HARI, SHARI, SINAYAKASAに ついて末加工布とそれほど差が認められない。一方， FUKURAMI と KISIMI では，有意の変化が認められる ものもある。しかし、全体として差はそれはど大きくな く，風合いに与える影響はそれはどないものと考えられ る。

\section{6 预光性}

絧の黄変現象はきわめて複雑であるが, 主として芳香 族アミノ酸のチロシンやトリプトファンなどの酸化で形 成された黄褐色のメラニン色素や黒褐色のフミン質に起 因すると考えられている[15]。この考えをもとに，絹轼 維の黄変ならびに脆化防止として，化学好理による光活 性基の不活性化 (Blocking) が研究されているが，実用 に供すには十分ではないとも言われている(16]。

ところで, フルオロアルキル基は强力な電子吸引性の 官能基であり，導入により化合物の反応性を低下させ化 学的に安定化させることが知られている。本研究のチ口 シンの選択的フルオロアルキル化を一種の Blocking $と$ みなせば，緗の树光性问上の可能性がある。この点につ いて，紫外線照射による黄变を時間的に追跡して検討し た。なお，黄変の評価は， $\mathrm{L}_{\mathrm{a}}$ 測色系における $\mathrm{b}$ 值の変 化から行った。その結果を図 9 に示す。

予想に反し，フルオロアルキル化をすると未改筫綃布

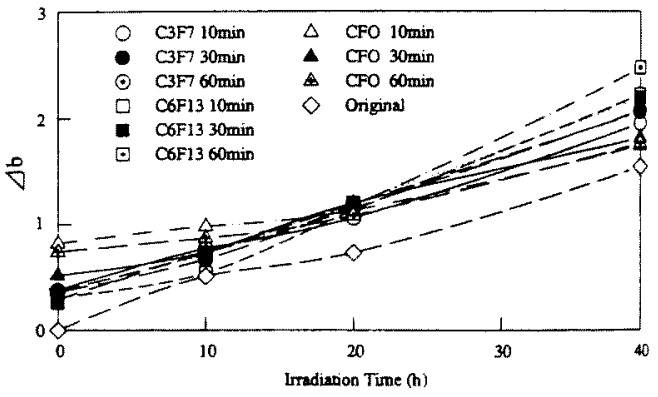

Fig. 9 Effect of time of irradiation by carbon arc on $\triangle \mathrm{b}$ of PFPO modified silk fabrics.

よりもb值は大きくなる結果が得られた。この傾向は， 照射時間が長くなるに従い顕著となった。ところで， CFO 改質試料は他の PFPO 好理試料と比べ初期の黄変 が著しかったが，CFO 改翼試料（30分好理）について フロン洗浄後水洗を行ったところ他のPFPO 処理試料と b 值にはとんど差がなかった。従って，絹に残留しだ゚ ーフルオロカルボン酸は強度低下だけでなく二次的に黄 変を促進すると考えられる。

柴外線照射にともなう絹系の引張り强度の変化を摆べ た結果，照射により強度は著しく低下した。照射前およ び40時間照射後の強度をb 值に对しプロットして図10に 亦す。両者の間には明らかな負の相関関係があり，フル オロアルキル化によって黄変ならびに脆化現象が強く現 れる結果となっており，予想とは大きく異なっだ。 この理由について，黄変はチロシンの光励起が引き金 


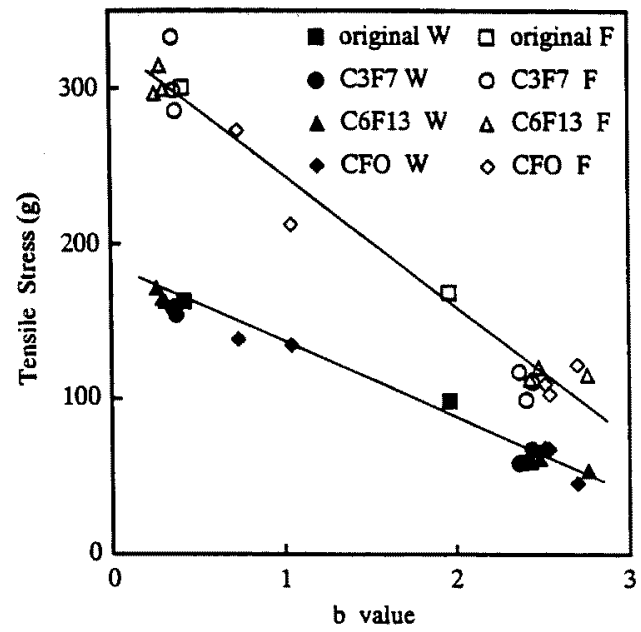

Fig. 10 Relations between tensile stress and $\mathrm{b}$ value for PFPO-modified fabrics with and without carbon arc irradiation.

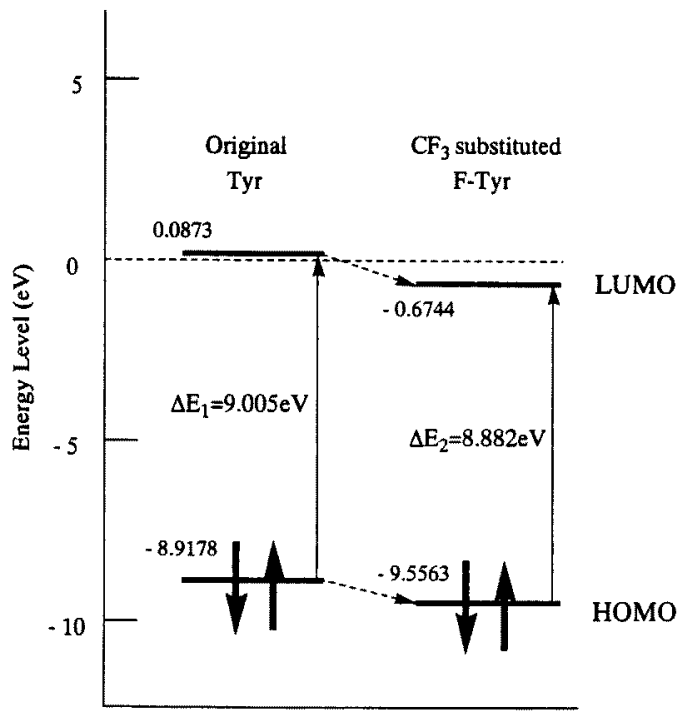

Fig. 11 Energy diagrams of HOMO and LUMO of unsubstituted tyrosine (Tyr) and $\mathrm{CF}_{3}$-substituted tyrosine (F-Tyr).

となっているものと仮定し，フルオロアルキル化による チロシンの反応性の変化について分子軌道法の立場から 検討を加えた。なお，計算プログラムの都合上，チロシ ン (Tyr) と。ートリフルオロメチルチロシン (F-Tyr) をモデルとして計算を行った。結果を図11に示す。

最高被占軌道 HOMO および最低空軌道 LUMOの軌道 の対称性には大きな変化は認められなかったが, 雨軌道 のエネルギー準位はフルオロアルキル化により大きく变
化した。HOMOは，フルオロアルキル化により元のチ ロシン自体の值よりも低くなり, 予想通り化学的に安定 化したことを示している。--方，F-TyrのLUMOの工 ネルギーも負の值 $(-0.6744 \mathrm{eV})$ となり, Tyrの反結 合性から結合性に転じ安定化されている。その結果, HOMO-LUMO 䠛移に必要なエネルギーがTyrの9.005 $\mathrm{eV}$ から F-Tyr では8.882 eV と小さくなっている。こ のことは，後者の方がより低いエネルギーの光により HOMOーLUMO 要移を起こすことを意味する。しかも， 励起状態であるLUMO が安定集位であることを含めて 考えると，光励起種が無置換の TyrよりもF-Tyrの方 が多くかつ寿命が長いことを示唆しており，黄変がより 起こりやすくなったと説明される。

\section{4. 結 論}

パーフルオロアルカノイルパーオキサイド（PFPO） による絹の表面改質を試みた結果，PFPOは非常に温和 な条件で䅌に含まれるチロシンを選択的にフルオロアル キル化した。改質反応は表面において有效に進行しバル クにはほとんど影響しなかった。フルオロアルキル化に より表面は㻋水化され带電性には大きな变化が認められ た。プラズマ処理と比べるとぬれ性への影響は小さいが， 強度变化などは起こさず風合いのの影響も小さかった。 しかし、フルオロアルキル化により耐光性は低下した。

\section{辢辞}

本研究を遂行するにあたり，装置の使用に便宜を御図 り下さいました大阪府立産業技術緿合研究所の木村裕和 氏，日本化学䄉維検査協会の広田利幸氏，天野行夫氏に 感謝いたします。また，分子軌道計算において御世話に なりました，大阪市立大学理学部の吉田潤一的に謝意を 表します。

本研究の一部は, 平成 5 年度緎維学会年次大会研究発 表会（平成 5 年 6 月，東京）で発表した。

\section{文䇆}

1. E. Kissa, "Handbook of Fiber Science and Technology: Vol. II. Chemical Processing of Fibers and Fabrics, Functional Finishes Part B" (M. Lewin and S. B. Sel 10. Eds.), Marcel Dekker, New York, p.143 (1984).

2. T. Kawase, Y. Doko, T. Fujii, and M. Minagawa, Sen'i Gakkaishi, 49, 267 (1993).

3. a) L. H. Hayes and D. D. Dixon, J. Fluoro. Chem., 10, 1 (1977); b) L. H. Hayes and D. D. Dixon, Text. Res. J. 47, 277 (1977). 
4. T. Yasuda, M. Gagzicki, and H. Yasuda, J. Appl. Polym. Sci: Appl. Polym. Symp., 38, 201 (1984).

5、奥野温子，澤裕子，家政誌，45，303（1994）。

6. Z. Chegxue, Z. Renmo, P. Heqi, J. Xianshan, Q. Yangling, W. Chengjiu, and J. Xikui, J. Org. Chem., 47, 2009 (1982).

7. R. Hiatt, "Organic Peroxides II" (D. Swern, Ed.), Wiley Interscience, Chap.8 (1971).

8. M. Yoshida, H. Amemiya, M. Kobayashi, H. Sawada, H. Hagii, and K. Aoshima, J. Chem. Soc., Chem. Com. mun., 1985, 234.

9. K. Ogino, M. Abe, K. Morikawa, H. Sawada, and M. Nakayama, J. Jpm. Oil Chem. Soc., 40, 1115 (1991).

10. T. Kawase, T. Fujii, M. Minagawa, H. Sawada, and
M. Nakayama, Text. Res. J., 64, 375 (1994).

11. 皆川 基, 「絹の科学」, 関西衣生活研究会, p.40 (1980).

12. B. Miller, "Surface Characteristics of Fibers and Tex. tiles", Part II (M. J. Schick, Ed.), Marcel Dekker, New York, p.417 (1977).

13. S. Kawabata and M. Niwa, J. Text. Inst., 80, 19 (1989).

14. W. Thiel, QCMP 002.

15. R. S. Asquith, L. Hirst, and D. E. Rivett, Text. Res. J., 40, 285 (1970).

16. 皆川 基,「絹の科学」, 関西衣生活研究会, p.476 (1980). 